\title{
ARTICLES
}

\section{DOWRY SYSTEM: A BLOT IN SOCIETY}

Dr. Poonam Sinha*I Mr. Robin Sinha**

* Lecturer in Department of Sociology, Nawada Vidhi Mahavidyalaya, Nawada, Affiliated M.U Bodh Gaya.

**Student, Chandigarh University, Punjab, India.

DOI: http://doi.org/10.47211/tg.2020.v07i03.016

\section{ABSTRACT}

The act of settlement represents a substantial danger to the life of females. Settlement is a well-established practice in Indian culture alluding to property or significant security given by one gathering to another as a thought for marriage. The cause of settlement fundamentally was the commitment of the spouse's family or without anyone else with the goal to support the spouse. This custom of settlement was begun in the archaic period. Ladies were skilled with riches what's more, gems from their folks during her marriage and this filled in as an instrument of monetary freedom for the lady of the hour even after marriage. This hazard is the underlying driver of practically all savagery against a wedded lady. Much of the time, after marriage, the issue of share will emerge. In the event that the spouse can't give all, which her significant other and parents in law request, her life in the lucky man's home becomes hopeless. She will be dealt with cold-bloodedly and at times, she may lose her life.

Key Words: Marriage, Dowry Deaths Dowry, Cruelty. India

\section{ABOUT AUTHORS:}

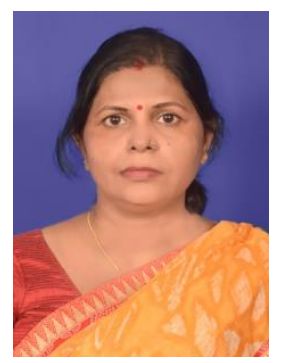

The author Dr. Poonam Sinha is Lecturer in Department of Sociology, Nawada Vidhi Mahavidyalaya, Nawada, affiliated to M.U Bodh Gaya.

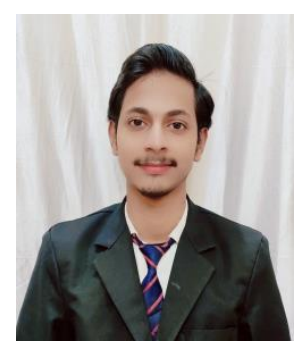

The author Mr. Robin Sinha is student in Chandigarh University, Punjab, India. 


\section{INTRODUCTION}

Relationships are made in paradise. A lady of the hour goes out to where she wedded. She having sweet memories with her people left all the memories and entered to start one more life at a wedding home there with a desire that she will see a different universe stacked with friendship in her significant other 's home. She surrenders her memories, yet moreover her last name gotra and womanhood. She is an ace not only to be a young lady in law, yet a young lady in all honesty. Really awful! The upsetting climb in the quantity of cases including baiting the as of late wedded youngsters for gift breaks the dreams In-laws are depicted to the bandits for executing mental fighting which wrecks the conjugal home. The Terrorist is endowment, and it's spreading its limbs each conceivable way.

\section{HISTORICAL BACKGROUND OF DOWRY SYSTEM}

Uttar Pradesh tops my list of the cases of dowry death with 2076 such deaths reported in the state during the year 2007, Accounting for $25.7 \%$ of the total 8093 cases reported all over India. Bihar positions second with 1172 cases representing $14.5 \%$ of the all-out cases revealed in the nation as per the official figures.

Cruelty cases against woman as per data Available
\begin{tabular}{|c|c|}
\hline \multicolumn{2}{|c|}{ During the years } \\
\hline$\underline{\text { Year }}$ & $\underline{\text { Cases }}$ \\
\hline 2009 & 89546 \\
\hline 2010 & 94041 \\
\hline 2011 & 99135 \\
\hline 2012 & 106527 \\
\hline 2013 & 118866 \\
\hline 2014 & 122872 \\
\hline 2015 & 113403 \\
\hline
\end{tabular}

Figure 1

To project issue evil, two important amendments were made in 1983 and 1986 respectively.

The 1983 act was a demonstration to alter me Indian reformatory code 1860, the code Criminal technique 1973 and the Indian Evidence Act, 1872 to curb the pitilessness by spouse and his family members in the Society.

A reading of section 498- Man as husband or relative or the mate of a girl subject such woman to mercilessness will be rebuked with confinement for a term which may contact three years and will in like manner be in danger to fine "Fierceness" connotes any stiff-necked direct which is of such a nature as is presumably going to drive the woman to end everything or to cause grave injury danger to life member or prosperity (Regardless of her mental or physical health) of the woman. Incitement of the Woman where such harassing is with the ultimate objective of compelling her or any individual related to her to fulfill any unlawful requirement for any property or noteworthy security or is a direct result of dissatisfaction by her or any individual related to her fulfills such need. A perusing of segment 304-B IPC would show that when an inquiry emerges whether an individual has submitted the offense of endowment passing of a lady what all that is vital is it ought to be indicated that soon before her unnatural demise, which occurred inside seven years of the marriage. The lapsed had been mistreated, by such a person, to unfeelingness or incitement for or with respect to enthusiasm for the enrichment. In the event that that has appeared, at that point the court will assume that such an individual has caused the share demise. It can thusly be seen that regardless of the reality whether such individual is legitimately answerable for the passing of the expire or not by temperance of the assumption, he is esteemed to have submitted The endowment demise if there were such brutality or provocation and that if the unnatural passing has happened inside a long time from the date of marriage. There is an assumption under Section 113-B of the Evidence Act as to be the share passing. It sets out that the court will assume that the individual who has exposed the expired spouse to remorselessness before her passing was caused. The share demise on the off chance that it is indicated that before her passing such lady has 
been oppressed, by the charged badgering is associated with any interest for endowment. Essentially This is the assumption that has been joined in segment 304-B I.P.C. additionally regardless of the reality whether the blamed has any immediate association with the passing or not, they will be dared to have submitted the share demise given different necessities referenced above are fulfilled.

Deliberately forcing women to cause miscarriage without women's consent. Whoever presents the offense portrayed in the last proceeding with zone without the consent of the woman if the woman is quick with a child will be rebuked with confinement everlastingly or with the confinement of either portrayal for a term which may contact ten years, and will similarly be liable to fine.

Death brought about by act finished with expectation to cause premature delivery who ever, with goal to cause the unsuccessful labor of a lady with kid, does any demonstration which comes the demise of such lady, will be rebuffed with detainment of either portrayal for a term which may stretch out to ten years and will likewise be obligated to fine if act is managed without the assent of the lady will be rebuffed with detainment forever or with the discipline previously mentioned. It isn't basic to this offense that the guilty party should realize that the demonstration is probably going to cause passing.

Meaning of cold-bloodedness is the essence of the offence under segment $498 \mathrm{~A}$. The world having significance in both the offences under segment 498 and under segment 304 B of IPC. It is important to portray the significance of pitilessness held by different Jurimatix.

The word cold blooded cruelty is to be used by human lead or human direct. It is the immediate association or as to conjugal duty. It is a course of bearing on one which is ominously affecting the other. The callousness may be mental or physical intentional or coincidental.

\section{LAWS RELATED TO DOWRY}

During the 1950s ruler Exhaust has seen that Judges have in every case painstakingly ceased from endeavoring a complete meaning of cold-bloodedness for the motivations behind wedding suits and experience has indicated the shrewdness of this course. It is problematic if, surely doable, by Legal announcement to make certain arrangements of the demonstration or immediate as having or without nature or quality which render them capable or deficient in all states of signifying callousness in circumstances where no physical hostility is declared, Each such exhibition must be concluded practically identical to its enveloping conditions and the physical or perspective or susceptibilities of the legitimate partner the desire for the punishable mate and the miscreant's data on the genuine or conceivable effect of his lead on the other's prosperity are to a great extent matters which may be convincing in settling on which side of the line a particular show clearly of direct lies (1). The Supreme Apex judgment court has seen that brutality may not need to be physical, even mental torment in the given case would be an instance of savagery and badgering inside the importance of area 304 B and 498 An of IPC.

A young lady aches for exceptional days ahead with desire and want while going into a marriage and if from the very after day the mate starts inciting her for not bringing gifts and calling her revolting. There can't be more noteworthy mental torment, provocation or cold-bloodedness for the lady. (2)

The possibility of mercilessness and its effect shifts from individual to individual similarly depending on the social and financial status to which such individual has a spot. "Callousness" for the explanations behind building up the offense under in this manner said section need not be physical, even mental torture or abnormal lead may signify mercilessness and incitement in a given case (3)

At the point when the lead doesn't comprise of direct activity against the other however just of offense, by implication influencing that person, for example, tipsiness, or sauntering or wrongdoing. At this point it can just appropriately be supposed to be focused on the other when it is done, not just for the delight of the childish wants of the person who does it yet additionally in some part with an expectation to harm the other or to cause hopelessness on that person. In the event of this sort, if there is no craving to harm or dispense hopelessness on the other. The lead possibly becomes remorselessness when the legitimate grievance of the blameless party incite hatred with respect to the next, which displays (shows plainly) itself in activities or words really or genuinely coordinated at the guiltless party (4)

The composite image ought to be attracted regarding the demonstrations occurrences or direct for finding out whether these sum to pitilessness, physical or mental, except if, such sort of physical or mental sick therapies when taken together lead to the intervene of industrious cold-bloodedness change of mercilessness can't stick (5) By section $498 \mathrm{~A}$ is the instance case the husband was harassing and humiliating the wife, by Instituting vexatious litigation against her, the court held that this section is wide enough to cover cruelty committed, through an abuse 


\section{ARTICLES}

of the litigation process. Here in the case the husband was suspecting the causality of the wife on the wedding night itself. (6)

Taking alcohol does not amount to cruelty. The court has held that the habit of the husband to take alcohol is not violence and therefore excuse. The court held that the deceased wife's inability to adjust to her husband's habits is not a form of any kind of cruelty. (7)

Mental brutality implies when either party causes mental torment distress or enduring of such a greatness that cuts off the connection between the spouse and the husband and aftereffect of which it gets outlandish for the gathering who has endured to live with the other party (8)

Ingredients of cruelty in constituting cruelty contemplated by section 498A

I. Any 'settled' lead which may be of this nature as is most likely going to drive the female partner to end everything.

II. Any 'willful' damage which is likely going to gravely injury the woman.

III. any 'willful' showing which will be likely going to make the life of the female partner hard in extremity or prosperity and harm whether physical or mental health of the woman.

Cold-bloodedness ought to be deliberate that neither each mercilessness nor badgering has a component of criminal culpability with the end goal of segment $498 \mathrm{~A}$. It would be additionally impulsive to order explicit acts or directs which are equipped for adding up to cold-bloodedness as such arrangement can't be placed in a restraint recipe.

Which means of Provocation under segment 498A The Hon'ble Delhi High Court held that where a connection of a lady is finished so as to force her to do any unlawful demonstration, for example, to satisfy unlawful or unethical need for property or important security? It adds up to provocation' as thought about by area 498A. Further held that rejection of blessings brought by her in marriage and comments passed may offend the spouse yet by so inspire bigger thoughts, These will present out a defense of either 'Remorselessness or badgering as mulled over by segment $498 \mathrm{~A}$ or area 306. (9)

The offence of enrichment passing in which the death of a woman occurs by any devours or generous injury or happens regardless of any mistake than under conventional conditions inside seven years of her marriage and it is shown that soon before her ens, she was presented to mercilessness or goading by her significant other or any relative of her better half for, or with respect to, any enthusiasm for offer such passing will be characterized "settlement end" and such mate or relative will be considered to have caused her demise.(10)

I. The downfall of a female partner should be achieved through utilization or any considerable injury or regardless than under a normal circumstance.

II. If death occurred before seven years of her marriage.

III. The female partner almost certainly was presented to hostility or Provocation by her husband or any relative of her husband's family.

IV. Such mercilessness or bullying should be for or with respect to demand of offer.

V. Such viciousness or bullying seems to have been administered to the woman soon before her passing.

The real situation of the current case demonstrates that passing was not in ordinary conditions. The Articulation "typical conditions" clearly implies nature passing. Different words. The articulation in any case than under ordinary conditions" signifies passing not being in the standard course however obviously under dubious conditions isn't brought about by consumes or real injury (11)

Denial on giving or taking Share the administrative body has instituted uncommon law on preclusion of endowment in India. The point of this Demonstration is to restrict the giving or taking of settlement in India. The point of this demonstration is to restrict the giving or producing of endowment with results from first July 1961. The Demonstration has experienced different changes like alterations of 1984, 1985 and 1986.

As shown by region 3 of the Demonstration, a person, after the inception of this exhibition, give or take assistance of the giving or taking of things, he/she would be at fault with confinement for a term which won't be under five years and with fine which won't be not less than Rs. 15000/ - or the proportion of the assessment of such settlement whichever is more (12). The court is locked in to drive fewer sentences than prescribed to record good and remarkable reasons in the Judgment. (13)

\section{CONCLUSION}

Indian law has tried its best to save deaths and crime done in the name of the dowry system but it is still very hard to control it. Except if the entire society accepts that settlement is underhanded except if there is a solid 


\section{ARTICLES}

mindfulness in the brains of the general population, except if each relative believes that at once she additionally is a little girl in-law, except if each mother believes that the treatment which she provides for her girl in law can likewise be gotten by her own little girl, the shades of malice of settlement will stay in the public eye. As well, society and anybody as an individual from the general public can do parts to forestall offenses of provocation, share passing, and so forth by thinking about the accompanying steps; Start rehearsing settlement forbiddance in the family, instruct the individuals from the family with the arrangements of law that requesting and tolerating or giving settlement is an offense. In the event that in any family there is a developing clash among the parents in law and the spouse, attempt to meddle to figure out the distinctions and teach them about the wrongs of the settlement framework. Since a lady is a critical individual from the family and is qualified for all the rights and benefits a man appreciates. A lot of work and effort is required to upgrade Indian law system to make it up to the mark. This can be achieved only with the help of the proper framework and judiciary. Dowry system will end only if there is proper awareness among each and every citizen of India.

\section{REFERENCES:-}

1. Jamieson V. Jamieson, (1952) IAll ER85

2. Pawn Kumar V. State of Haryana (1998) $3 \mathrm{sec} 309$.

3. Gananath Pathak V. State of Orissa (2002) 2 Sec 619

4. Kaslef sky V. Karlesky. 19502 All ER 398

5. Savitri Devi V. Ramesh Chand (2003) 6ILD251 (Del)

6. Mukund Chints V. Maduri Chitints AIR 1992 SC 1804 : 1992 Cr. L.J 71

7. Harichandra V. State of M.P. 1987 Cr. L.J 1724

8. Hanumantha Raov. S Ramani (1999) 3 Sec 620

9. Savitri Devi. V. Ramesh Chand (2003) 6IL D251) Deb)

10. Section 304 B (1) of IPC was inserted by the Dowry - Prohibition (Amendment) Act. 1986.

11. Shanti V. State of Haryana. (1991) $1 \mathrm{sec} 371$ also sec Kailash VC state of MP (2006) INSC 633 